\title{
SATYRA NA AUGUSTA ZALESKIEGO, CZYLI O SPORZE WOJCIECHA WASIUTYŃSKIEGO Z ,SYRENĄ" PARYSKĄ
}

\author{
Krzysztof TARKA (Uniwersytet Opolski)
}

Na łamach emigracyjnego tygodnika „Syrena”, wydawanego w Paryżu w numerze 81 z 21 sierpnia 1949 roku, ukazała się anonimowa satyra Elekcja Augusta Czwartego (fragment z pamiętników Imci Jana w Oleju Szelki z Konopi). Jej autor, stylizując się na osiemnastowieczną polszczyznę, w dowcipny sposób nawiązywał do zaprzysiężenia Augusta Zaleskiego na stanowisku prezydenta $\mathrm{RP}^{1}$.

Po śmierci prezydenta Władysława Raczkiewicza w 1947 roku emigrantów podzielił spór o obsadę stanowiska głowy państwa. Konkurentami do fotela prezydenckiego byli Tomasz Arciszewski, premier rządu, desygnowany w 1944 roku na następcę prezydenta oraz August Zaleski, były minister spraw zagranicznych i urzędujący szef kancelarii cywilnej prezydenta, którego śmiertelnie chory Raczkiewicz w ostatnich tygodniach życia wyznaczył swoim następcą. Zmiany tej nie uznał Arciszewski i jego stronnictwo - Polska Partia Socjalistyczna. Zgodnie z decyzją Raczkiewicza po jego śmierci nowym prezydentem 9 czerwca 1947 roku został Zaleski. Socjaliści, powołując się na „umowę paryską”, przypominali, że Raczkiewicz, obejmując w 1939 roku urząd prezydenta, oświadczył, że będzie korzystał ze swoich konstytucyjnych uprawnień „W ścisłym porozumieniu” z premierem. Ponieważ prezydent wyznaczył swojego nowego następcę bez konsultacji z szefem rządu oraz socjalistami, ci uznali ją za bezprawną. Kryzys czerwcowy miał bardzo poważne konsekwencje. Doprowadził nie tylko do dymisji gabinetu Arciszewskiego, ale przede wszystkim do ciągnącego się przez następne ćwierć wieku sporu o prezydenturę oraz dekompozycji „,polskiego” Londynu i formalnego zdublowania emigracyjnych władz ${ }^{2}$.

\footnotetext{
${ }^{1}$ Elekcja Augusta Czwartego (fragment z pamiętników Imci Jana w Oleju Szelki z Konopi), Syrena $1949 \mathrm{nr} 81$, s. 8.

${ }^{2} \mathrm{Na}$ temat sporu o prezydenturę i prób zjednoczenia emigracji zob.: A. Friszke, Życie polityczne emigracji, Warszawa 1999, s. 71-214, 368-380; D. Górecki, Polskie naczelne władze
} 
Jak się niebawem okazało, autorem utworu wydrukowanego w „Syrenie” był znany publicysta i działacz Stronnictwa Narodowego, Wojciech Wasiutyński. Po demobilizacji z 1 Dywizji Pancernej, stacjonującej na terenie okupowanych Niemiec, w październiku 1947 roku Wasiutyński osiedlił się wraz z rodziną w Londynie, gdzie został redaktorem naczelnym „Myśli Polskiej”. Satyrę Elekcja Augusta Czwartego Wasiutyński napisał w końcu 1947 roku dla urozmaicenia „opłatka” Stronnictwa Narodowego w Londynie. Czytał ją na owym „opłatku” w gronie przyjaciół politycznych, następnie zaś na wieczorze z okazji zjazdu korporacyjnego w Londynie. Utwór nie był jednak przeznaczony do druku i miał tylko dwie kopie, z których jedną Wasiutyński pożyczył znajomemu do przeczytania. Gdy blisko dwa lata później dowiedział się, że ,jakieś nieznane” mu pismo polskie, wychodzące w Paryżu, ogłosiło bez podania nazwiska i „w formie skażonej” (wersja satyry opublikowanej w „Syrenie” nieznacznie odbiegała od oryginału) jego żart, był zdumiony i oburzony. W liście z 10 września 1949 roku do redakcji paryskiego tygodnika „Placówka” dodał: „Nadużycie to krzywdzi mnie moralnie i materialnie, wobec czego skierowałem sprawę na drogę postępowania prawnego"3.

Zarzuty pod adresem „Syreny” Wasiutyński powtórzył w późniejszym liście do Kajetana Morawskiego, byłego ambasadora RP w Paryżu i nieoficjalnego przedstawiciela emigracyjnych władz nad Sekwaną. Publicysta i działacz Stronnictwa Narodowego podkreślił, że redakcja „Syreny” naruszyła jego prawa autorskie, naraziła go także na straty i szkody moralne oraz materialne. Twierdził, że ten „samowolny czyn” wyrządził mu „dotkliwą krzywdę”: „Ukazanie się utworu w sierpniu 1949 w obcym mi organie - argumentował Wasiutyński - wywołało znaczne poruszenie w sferach literackich i społecznych polskich i spowodowało dla mnie przykrości ze względu na treść utworu i na osoby, których w przekonaniu czytelników mógł dotyczyć". Strata materialna, którą poniósł, polegać miała również na uniemożliwieniu mu późniejszego wydania utworu w sposób zgodny z jego „zamierzeniami literackimi”. Wasiutyński domagał się zamieszczenia w tygodniku „odpowiedniego wyjaśnienia” oraz wypłaty odszkodowania w wysokości 50000 franków francuskich. Uważał nawet, że ze względu na „okoliczności sprawy” odszkodowanie powinno być znacznie wyższe. Spór miał rozstrzygnąć sąd polubowny, jednak arbitrom stron nie udało się uzgodnić osoby superarbitra, o co Wasiutyński obwiniał „Syrenę”. Nie chcąc kierować sprawy do sądu francuskiego, 11 sierpnia 1950 roku zwrócił się listownie do Kajetana Morawskiego z prośbą o powołanie sądu obywatelskiego. Każda ze stron miała wyznaczyć swojego arbitra, Wasiutyński wskazał mieszkającego Paryżu adwokata i działacza SN Bohdana Gajewicza. Gdyby arbitrom ponownie nie udało się uzgodnić osoby superarbitra, proponował, aby Morawski wyznaczył go według swego uznania. Wasiutyński oczekiwał, że w ciągu dwóch tygodni od wydania orzeczenia redakcja „Syreny” zamieści satysfakcjonujące go wyjaśnienie oraz wypłaci mu tytułem odszkodowania 50000 fran-

państwowe na uchodźstwie w latach 1939-1990, Warszawa 2002, s. 56-162; R. Habielski, Kryzysy prezydenckie 1947 i 1954 roku. Ich antecedencje i następstwa, [w:] Warszawa nad Tamiza. $Z$ dziejów polskiej emigracji politycznej po drugiej wojnie światowej, red. A. Friszke, Warszawa 1994, s. 19-32; P. Ziętara, Misja ostatniej szansy. Próba zjednoczenia polskiej emigracji politycznej przez gen. Kazimierza Sosnkowskiego w latach 1952-1956, Warszawa 1995.

${ }^{3}$ W. Wasiutyński, W sprawie „Elekcji Augusta Czwartego”, Placówka 1949 nr 51, s. 4. Szerzej na temat Wasiutyńskiego zob.: B. Smolik, Myśl polityczna Wojciecha Wasiutyńskiego, Toruń 2004; W. Turek, Wojciech Wasiutyński 1910-1994. Biografia polityczna, Kraków 2008. Obaj autorzy nie wspominają o satyrze Wasiutyńskiego. O sprawie nie wspomina również sam W. Wasiutyński, Prawa strona labiryntu. Fragmenty wspomnień, oprac. i red. W. Turek, Gdańsk 1996. 
ków ${ }^{4}$. „Zapomniał”, że o werdykcie i ewentualnej wysokości odszkodowania zadecydować miał przecież sąd obywatelski.

O propozycji Wasiutyńskiego 21 sierpnia 1950 roku Morawski zawiadomił pisemnie Mariana Serafińskiego, kierownika spółki wydającej „Syrenę”. Ten przebywał akurat na wakacjach w Grasse, obiecał jednak, że gdy w połowie września wróci do Paryża, dołoży wszelkich starań, by sprawa między „Syreną” a Wasiutyńskim została jak najszybciej załatwiona. Przy okazji poinformował Morawskiego, że już kilka miesięcy wcześniej dał Wasiutyńskiemu pisemną zgodę na załatwienie sporu przez sąd polubowny ${ }^{6}$.

Jesienią 1949 roku w roli superarbitra wystąpić miał prof. Henri Mazeaud. Jego kandydaturę zaproponowała Irena Ruszkowska, arbiter Wasiutyńskiego. Arbitrem „Syreny” był Alfred Sas-Korczyński. Jednak gdy sąd polubowny miał przystąpić do rozstrzygnięcia sprawy, Mazeaud odmówił przyjęcia stanowiska superarbitra. Ruszkowska i Sas-Korczyński próbowali jeszcze doprowadzić do ugody, ale ich mediacja nie przyniosła rezultatu, jak stwierdził Serafiński, ze względu na zbyt daleko idące żądania Wasiutyńskiego. Wówczas komitet redakcyjny „Syreny” zaproponował jako superarbitra prof. Henri de Montforta lub Zygmunta Dygata. Obie kandydatury strona przeciwna jednak odrzuciła. Na początku 1950 roku Ruszkowska zapowiedziała, że Wasiutyński zamierza poprosić o rozstrzygnięcie sporu Morawskiego. Wydawcy i redakcja „Syreny", wykazując dobrą wolę, 10 lutego za pośrednictwem Sas-Korczyńskiego zadeklarowali zgodę na kandydaturę byłego ambasadora jako superarbitra. Wbrew zapowiedzi Wasiutyński nie zwrócił się jednak wówczas do Morawskiego i przez kolejne pół roku sprawa nie ruszyła z miejsca? ${ }^{7}$.

Oskarżeni uważali zresztą, że w żaden sposób nie naruszyli praw autorskich Wasiutyńskiego i działali w dobrej wierze, publikując rzecz już rozpowszechnioną w środowisku polskim. „Syrena” otrzymała satyrę z dwóch źródeł: od przyjaciół pisma z Niemiec i Londynu, a maszynopis nie był podpisany. $Z$ informacji, które dotarly do redakcji wynikało, że utwór przez wiele miesięcy krążył w anonimowych odpisach w „polskim” Londynie. Przed drukiem paryski tygodnik bezskutecznie próbował ustalić nazwisko autora satyry. Jeszcze w końcu października 1949 roku Serafiński złożył do akt sądu polubownego pisemne oświadczenia 12 osób (między innymi gen. Stanisława Kopańskiego, Kazimierza Okulicza czy gen. Kazimierza Wiśniowskiego), które stwierdziły, że wiosną 1949 roku czytały ten utwór w odpisach, nie miały jednak pojęcia, kto był jego autorem. W drodze ugody tygodnik gotów był wypłacić Wasiutyńskiemu honorarium $\mathrm{w}$ wysokości, jakie pismo płaciło autorom innych tekstów drukowanych na jego łamach. Wasiutyński żądał jednak znacznie wyższego odszkodowania. Serafiński wyraził też zdziwienie, że Wasiutyński w liście do Morawskiego z 11 sierpnia 1950 roku nazwał „Syrenę” „obcym mu organem”. Przypominał, że wydawcą tygodnika były Federacja Związków Obrońców Ojczyzny oraz Stowarzyszenie Polskich Kombatantów Oddział Francja. Członkiem SPK był również Wasiutyński, a w końcu sierpnia 1950 roku został nawet wiceprzewodniczącym Rady Głównej SPK. Winę za niezałatwienie sprawy Serafiński przypisywał wyłącznie Wasiutyńskiemu. Obawiając się przewlekłej procedury przed sądem obywatelskim, odrzucił też jego najnowszą propozycję. Aby jednak ostatecznie zakończyć ciągnący się od ponad roku spór, „Syre-

\footnotetext{
${ }^{4}$ Biblioteka Polska w Paryżu, Archiwum K. Morawskiego (dalej: BPP, AKM), tymcz. 45, Pismo W. Wasiutyńskiego do K. Morawskiego z 11 sierpnia 1950.

${ }^{5}$ BPP, AKM, list K. Morawskiego do M. Serafińskiego z 21 sierpnia 1950.

${ }^{6}$ BPP, AKM, list M. Serafińskiego do K. Morawskiego z 29 sierpnia 1950.

${ }^{7}$ BPP, AKM, list M. Serafińskiego do K. Morawskiego z 28 września 1950.
} 
na” gotowa była wypłacić Wasiutyńskiemu wyjątkowo wysokie — jak na możliwości emigracyjnego tygodnika - honorarium w wysokości 5 tys. franków (,Syrena” płaciła zazwyczaj 1 tys. franków honorarium). Wypłata odszkodowania, którego domagał się Wasiutyński ze względów finansowych była niemożliwa, a jego zasądzenie groziło upadkiem pisma ${ }^{8}$.

Morawski, chcąc doprowadzić do szybkiego rozstrzygnięcia sprawy, na początku października 1950 roku zaproponował Wasiutyńskiemu, że sam może wystąpić jako jednoosobowy arbiter w jego sporze z „Syreną”: „Myślę, że w razie Pańskiej zgody — argumentował - trudno by było przeciwnej stronie tego rodzaju propozycję odrzucić"9 . Już dwa dni później propozycję ambasadora Wasiutyński przyjął ,jak najchętniej" ${ }^{\prime 10}$, przecież i jemu trudno byłoby ją odrzucić. W tej sytuacji Morawski zaproponował Serafińskiemu, że może się podjąć roli superarbitra w sporze z Wasiutyńskim ${ }^{11}$. Jak można się było spodziewać, również Serafiński zadeklarował „całkowitą na to zgodę" $"$. Sprawa ciągnąca się miesiącami nabrała przyspieszenia.

Na 26 lutego 1951 roku Morawski zaprosił do siebie mecenasa Gajewicza, pełnomocnika Wasiutyńskiego oraz Stanisława Paczyńskiego, redaktora „Syreny” w celu złożenia ewentualnych oświadczeń ${ }^{13}$. Po wysłuchaniu stron i zapoznaniu się z przedstawionymi przez nie wcześniej materiałami, 17 marca 1951 roku Morawski, jako jednoosobowy arbiter, wydał ostateczne orzeczenie w sprawie wytoczonej przez Wasiutyńskiego przeciwko „Syrenie”. Emigracyjny dyplomata podkreślił, że satyra, napisana przez Wasiutyńskiego, została wydrukowana przez paryski tygodnik bez podania nazwiska autora oraz bez jego wiedzy i zgody. Ponieważ utwór ten był wcześniej rozpowszechniany przez osoby trzecie w formie niepodpisanej ulotki, niezawierającej zastrzeżeń, co do przedruku, Morawski stwierdził, że redakcja „Syreny”, zamieszczając go na swych łamach, choć naruszyła prawa autorskie „wybitnego pisarza”, to uczyniła to niewątpliwie w sposób nieświadomy i niezamierzony. W ciągu 15 dni od otrzymania orzeczenia „Syrena” miała na pierwszej stronie wydrukować oświadczenie przepraszające Wasiutyńskiego oraz wypłacić mu honorarium autorskie w wysokości 5 tys. franków, a więc pięciokrotnie wyższe od płaconego zwyczajowo przez redakcję i symboliczne odszkodowanie w wysokości 1 tys. franków ${ }^{14}$.

Wydawcy i redakcja paryskiego tygodnika wykonali orzeczenie superarbitra. W numerze z 31 marca 1951 roku ukazało się oświadczenie redakcji „Syreny”, przepraszające Wasiutyńskiego „za mimowolne naruszenie jego prawa autorskiego i straty oraz nieprzyjemności, jakie mogły dla niego stąd wyniknąć”. Redakcja wyjaśniała, że

${ }^{8}$ BPP, AKM, listy M. Serafińskiego do K. Morawskiego z 28 września i 6 listopada 1950. Do listu z 6 listopada Serafiński załączył oświadczenia 12 osób. Na przełomie 1949 i 1950 r. sześć osób z wymienionej dwunastki na prośbę Wasiutyńskiego ponownie napisało oświadczenia dotyczące czasu i okoliczności, w których zapoznali się z satyrą. Nie wnosiły one niczego nowego do sprawy. Komplet oświadczeń Wasiutyński za pośrednictwem swojego arbitra przekazał Morawskiemu; zob.: BPP, AKM, list B. Gajewicza do K. Morawskiego z 11 grudnia 1950 wraz $\mathrm{z}$ oświadczeniami sześciu osób.

${ }^{9}$ BPP, AKM, list K. Morawskiego do W. Wasiutyńskiego z 3 października 1950.

${ }^{10}$ BPP, AKM, list W. Wasiutyńskiego do K. Morawskiego z 5 października 1950.

${ }^{11}$ BPP, AKM, lst K. Morawskiego do M. Serafińskiego z października 1950.

${ }^{12}$ BPP, AKM, lst M. Serafińskiego do K. Morawskiego z 19 października 1950.

${ }^{13}$ BPP, AKM, listy K. Morawskiego do B. Gajewicza i S. Paczyńskiego z 21 lutego 1951.

${ }^{14}$ BPP, AKM, Orzeczenie K. Morawskiego w sprawie W. Wasiutyński kontra „Syrena” z 17 marca 1951. 
zamieszczając satyrę nie znała jej autora i sądziła, że jest to powielane pismo ulotne ${ }^{15}$. Na tym zakończył się spór Wasiutyńskiego z „Syreną”.

Elekcja Augusta Czwartego. Fragment z pamiętników Imci Jana w Oleju Szelki z Konopi $^{16}$

Anno Domini millesimo septingentesimo quadragesimo septimo ${ }^{17}$ zima była okrutnie sroga tak, że wszystkie grusze na wierzbach wymarzły. Staliśmy natenczas in hiberniis $^{18} \mathrm{w}$ królestwie hanowerskim kiedy wieść przyszła, iż król jegomość Władysław ${ }^{19}$ in extremis ${ }^{20}$ a wraz, że i zmarł.

Elekcję konwokowano do Lądynia, wsi znacznej nad rzeką po polsku Tamżą a z ruska Tamizą zwącą się. Chociam in personam ${ }^{21}$ przybyć tam nie mógł gwoli odległości i ekspensów a takoż iż było to w czasie żniwnym na kawę, ale mi wszystko sąsiad mój tam obecny Imć Pan Kaczkowski z Wierutnik i socjusz jego podczaszyc Bujdo dokumentnie opowiedzieli jakobym tam był corpore praesens ${ }^{22}$, co i niniejszym impartialiter refero $^{23}$.

Owóż było między Senatorami conventum ${ }^{24}$, że vivente rege ${ }^{25}$ elekt ma być desygnowany i że kogo król Jegomość wymieni, tego stany bez żadnej opozycji elegere debent $^{26}$. Król Władysław Piąty, pan wielkiej zacności ale konstancji mniejszej, był niegdyś na elekta wskazał pana hetmana polnego Sosnkowskiego ${ }^{27}$, in quo valde confide$b a t^{28}$, ale że i panowie rada wielce nań nastawać zaczęli a wraz i obce potencje się ozwały i powiadano nawet, że dwór cesarski pana hetmana polnego pomazańcem nie uzna, zreflektował się i elekta in persona pana kasztelana wareckiego Arciszewskiego ${ }^{29}$ nominavit $^{30}$, któremu też potem pieczęć wielką konferował. Toż gdy przyszła wieść, że król Władysław na zamku w Walijskim zachorzał i spes omnis abest ${ }^{31}$, pan kanclerz wielki, na wiek sędziwy nie bacząc, ku pana konającego wezgłowiu ruszył nie mieszkając. Ale jako w leciach będący, stanął na drodze dla odpoczynku w karczmie pod Złotą Głową. Tam mu pan hetman wielki i pan instygator Tomaszewski ${ }^{32}$ drogę zabieleli i o zgonie pana donieśli. Zatroskał się pan kanclerz ale nie tak bardzo aż gdy mu pergamin

${ }^{15}$ Oświadczenie Redakcji „Syreny”, Syrena 1951 nr 165, s. 1. Tekst oświadczenia zob. też: BPP, AKM, tymcz. 45.

${ }^{16}$ Biblioteka Uniwersytecka w Toruniu, Archiwum Emigracji, Archiwum W. Wasiutyńskiego, sygn. AE/WW/XIV. Anonimowy odpis satyry z minimalnymi różnicami znajduje się również w zbiorach Biblioteki Polskiej w Paryżu, Archiwum K. Morawskiego, tymcz. 45. Wersja drukowana zob.: Elekcja Augusta Czwartego (fragment z pamiętników Imci Jana w Oleju Szelki z Konopi), Syrena 1949 nr 81, s. 8.

${ }^{17}$ (łac.) - Roku Pańskiego 1747.

18 (łac.) - w uśpieniu.

${ }^{19}$ Władysław Raczkiewicz (1885-1947), prezydent RP.

${ }^{20}$ (łac.) - na skraju, wyczerpany.

21 (łac.) - osobiście.

22 (łac.) - fizycznie obecny.

${ }^{23}$ (łac.) - bezstronnie przedstawiam.

24 (łac.) - układ, umowa.

${ }^{25}$ (łac.) - za życia króla.

26 (łac.) - powinny wybrać.

${ }^{27}$ Kazimierz Sosnkowski (1885-1969), generał, naczelny wódz.

${ }^{28}$ (łac.) - najbardziej zaufanego

29 Tomasz Arciszewski (1877-1955), premier RP, polityk Polskiej Partii Socjalistycznej.

${ }^{30}$ (łac.) - wyznaczył.

${ }^{31}$ (łac.) - beznadziejnie.

32 Tadeusz Tomaszewski (1881-1950), prezes Najwyższej Izby Kontroli, polityk Polskiej Partii Socjalistycznej. 
pieczęcią mniejszą opatrzony i pismo manu propria $^{33}$ króla nieboszczyka zawierający okazali, a wraz rzekli, że król opinią był zmienił, pana kanclerza revocavit ${ }^{34}$ i elektem eius loco ${ }^{35}$ pana kanclerza nadwornego czyni. Pan kanclerz wielki, któren wedle wieku swego i słyszał, zrazu intelligere non poterat ${ }^{36}$, lecz dłoń do ucha uniósł i „,co proszę?” pyta. Aż gdy manuskrypt okazany przeczytał, na obliczu posiniał, zaś oburącz za siwą brodę się ułapił i jedno tylko słowo „Gorze” wielkim głosem wyrzucił. Zaczym, ani się żegnając przed karczmę wybiegł, konia podać kazał — a miał rumaka krwi orientalnej, cudnego barzo, imieniem Pera - nań skoczył i ku stolicy pognał, że jeno wyłogi czerwonego kontusza nad gościńcem powiały.

Pole elekcyjne antiquo modo ${ }^{37}$ było z szopa senatorską pośrzodku i bracią mniejszą obozującą cum rumore ${ }^{38}$ dokoła. Nim jeszcze senatorowie obradzać inciperunt ${ }^{39}$, już wieść o dwojakiej kandydaturze rozeszła się między szlachtą i ta w dwa koła zbierać się zaczęła: kto za Augustem a kto za Tomaszem. W pana Augustowym kole zrazu Litwa i Ruś stanęła jako więcej od tego pana auxiliów ${ }^{40}$ przeciw Moskwicinowi się spodziewająca. Litwie przewodził ciwun żmudzki pan Catkiewicz ${ }^{41}$, mąż tuszy okazałej i do gniewu srogiego prędki. „August, wojenny to pan — mówił - a Tomasz cudzoziemskich podszeptów rad słuchać, w gołocie się lubuje i ze słabnącej ręki miecz łacno mu wypaść może”. Przeciwnie w pana Tomaszowym kole rej wodzili Nidzianie, szlachta ambitna a uboga, darować nieboszczykowi królowi nie mogąca, że im żadnego, bodaj drążkowego krzesła w senacie nie konferował a oraz przypisująca to instygacji pana kanclerza nadwornego.

I o mało do burdy nie doszło gdy pan Godlewski ${ }^{42}$, kasztelan wileński głosem strasznym wołać począł, że pan kanclerz herezją się para i od obrzydliwości markspaństwa jest nie wolny. Tedy pan podsędek Olszewski ${ }^{43}$ parol szlachecki dał, że pan kanclerz żadnej księgi Marksa nie czytał, zaczym towarzystwo się uspokoiło.

W szopie senatorskiej, gdy się panowie zjechali, oba pisma króla nieboszczka odczytano i wraz imieniem pana kanclerza wielkiego pan podskarbi Quapiński ${ }^{44} \mathrm{z}_{\mathrm{C}}$ Chałupek i pan chorąży czerwonogrodzki Adam herbu Ciołek ${ }^{45}$ protestacją wnieśli, wywodząc iż elekcja vivente rege odbyć się musiała i w pactach conventach inclusum erat ${ }^{46}$, jako król jegomość nic bez zgody senatu de publicis ${ }^{47}$ nie postanowi, więc secundum decretum non est validum ${ }^{48}$. Przeciwił się temu ksiądz biskup śląski Sopicki ${ }^{49}$, powiadając, iż senatus consultum ${ }^{50}$ być nie mogło, bo się senat nie zebrał i dopiero teraz gdybyśmy per maioritatem ${ }^{51}$, które w czasie bezkrólewia ius est, nullitatem secundi decre-

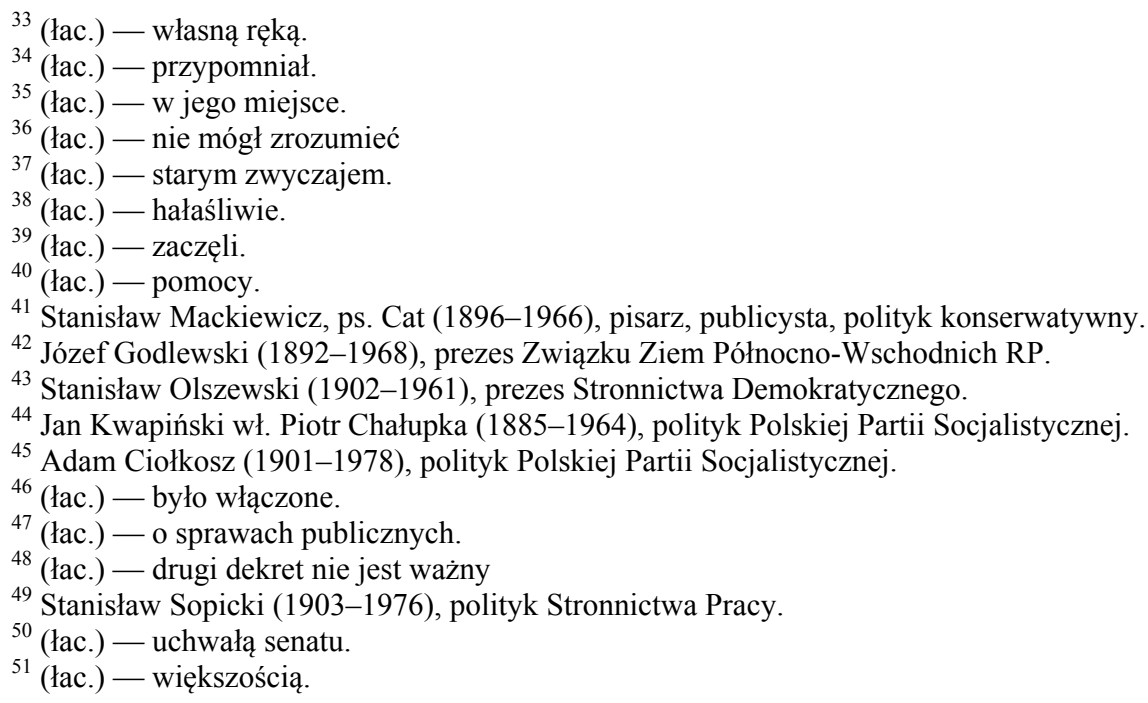


$t i^{52}$ ferowali, primum decretum byłoby revalidatum ${ }^{53}$. Obruszył się na to wielce pan chorąży Ciołkosz: „A gdzie wolność szlachecka - woła gdzie populi nobilium consensus $^{54}$ ? Waszmościowie mi tu od zadu absolutum dominium ${ }^{55}$ wprowadzacie". A na to biskup śląski: „Wotujmy, wotujmy”. „Nie masz wotowania jak per unanimitatem ${ }^{56}$, takie jest tego królestwa starodawne prawo”. „Elekcja jest zawżdy pod kapturem unanimitas suspenditur "57". I biskup śląski, choć mizernego wzrostu człek, piersią na chorążego czerwonogrodzkiego nastaje. Tu pan oboźny Wiśniowski, Augustów nietajny poplecznik a o losy wotów niespokojny przerwał powaśnionym i na pana Bieleckiego ${ }^{58}$, starostę endeckiego wskazując, rzekł: „Radzibyśmy waszej miłości zdanie znać”. Poprawił pan starosta pas na brzuchu, który zgoła niebylejaki miał, wąsa pogładził, odchrząknął i mówi: „Nie tajno waszmościom, że oba reskrytpta autentyczne a temu królestwu bym ubliżył, gdybym rzekł, że oba kandydaci nie najzacniejsi. W tem mi się widzi rzecz, by jednego a nie obu naraz wybrać i o to waszmość panów a mnie milych braci kornie upraszam”. „Ale którego, o toż pytamy”. „Zali godzi się bym przed hetmanami i ministrami głos brał". Nie było tedy rady jeno do wotów się brać. Za Augustem tedy wota dali hetmani - wielki i polny Komorowski ${ }^{59}$ i regimentarz Kopański ${ }^{60}$ i pisarz polny Kukiel ${ }^{61}$ i biskupi. Co widząc pan chorąży czerwonogrodzki ze stolca się porwał, za nim pan podskarbi i pan wojski Haluch ${ }^{62}$. „Protestujemy! Nie uznajemy!” Zaczem pan Haluch ode drzwi szopy „Sisto activitatem "63 i umknął. „A waćpan?” pyta starosty endeckiego pan hetman polny. — „Wasze za kim wotujesz?”. „Jakoż mam za Tomaszem wotować, kiedy nie masz ktoby go proponował".

Ledwie kanclerscy przed szopę wyszli aż ich tłum szlachty nidzkiej opada. Nim relację usłyszą już do dzieła currunt $^{64}$. Jeden w obóz leci z krzykiem ,absolutum dominium mości panowie!”, drugi o obronę złotej wolności woła. Trzeci na beczce pergamin rozwija, czwarty inkaust i pióra podaje panu kanclerzowi: „Akt konfederacji piszemy, jako libertatis defensores ${ }^{65}$ się konstytuujemy, przeciw absolutum dominium się wiążem”. „Na pohybel opressorom”. I wnet wszystkich do sygnowania konfederacji trahunt $^{66}$. Nie przepuszczając nawet przeorowi bernardynów Sulimirskich, któren mniemał, że petycją w sprawie wakujących opactw sygnuje. Na to któryś ciżbie: „Hańba, zdrada, Ruś pohańcom oddają!”. Toż dopiero szlachta kresowa obojga obrządków, ut scitum $^{67}$ do korda skora, coraz ciaśniej napiera na kanclerskich. Wszelako uwagę wszystkich odwrócił pan ciwun Catkiewicz. Ten, na koniu siedząc, wodze puścił, rękami za czub się targać począł i krzyczy: „O prolatas lenkas! ${ }^{68}$ Za cóż my nieszczastnyje z nimi ta unia zawarli? Dziś na pohańbienie święte prawa Litwy wydane i głosu jej

${ }^{52}$ (łac.) - jest prawem, unieważnili drugi dekret.

${ }_{54}^{53}$ (łac.) - pierwszy dekret odzyskałby swą ważność.

54 (lac.) - szlachty przyzwolenie.

55 (łac.) - władza absolutna.

${ }_{57}^{56}$ (łac.) - jednomyślnie.

57 (łac.) - zawiesza się jednomyślność.

${ }^{58}$ Tadeusz Bielecki (1901-1982), prezes Stronnictwa Narodowego.

59 Tadeusz Komorowski, ps. Bór (1895-1966), generał.

${ }^{60}$ Stanisław Kopański (1895-1976), generał.

${ }^{61}$ Marian Kukiel (1895-1973), generał.

${ }^{62}$ Franciszek Haluch (1893-1963), polityk Polskiej Partii Socjalistycznej.

${ }^{63}$ (łac.) - wycofuję się.

${ }^{64}$ (łac.) - pędzą, spieszą, biegną.

65 (łac.) - obrońcy wolności.

66 (łac.) - ciągną.

${ }^{67}$ (łac.) - jak postanowienie, jak uchwała.

68 (łac.) - potomstwo (lit.) - Polaków. 
nie ważą jakby się godziło. Konfederację psubraty piszą a o Smoleńsku i Disnie zabuli. Precz z pachołkami cesarskimi! Vivat Augustus Rex! ${ }^{69}$ ".

W szopie senatorskiej tymczasem czekano aż się pachołek wysłany do pana kanclerza wielkiego wróci i respons przyniesie czy się pan kanclerz ubłagać nie da. I byłby ponoć nawrócić rad, gdy mu gniew minął, lecz swoi mu nie dali. „Jakże to — powiada pan Zaremba $^{70}$, kasztelan paryski — to wasza miłość w rękę Augusta ucałujesz, za pana miłościwego uznasz?”. „Nie ucałuje”. „No to i wrócić nie możesz”. „Isto nie mogę”. I tak rzecz na niczym spełzła. Gdy tedy pachołek wrócił, powiada ksiądz prymas Berezowski ${ }^{71}$ niechętnie się ze stolca unosząc: „Jak ojca rodzonego kochałem imć pana kanclerza, w wielu bitwach śmy się potykali i jako waszmoście wiecie, jeszcze za króla Stanisława razem żeśmy posłowali. Sed patria prima ${ }^{72}$. Mości panowie czas nam wyjść z szopy a elekta ogłosić".

Widząc zasię prymasa wychodzącego i wielki krzyk hetmańskich, pan kanclerz wielki na pana podskarbiego spoziera, a ten w głos: „Nic tu po nas”. I ani wstecz nie poglądając, gniewem kipiący, każdy do swojego województwa odeszli.

Jam najprzedniejszych panów Rzeczypospolitej ujrzał, gdym do stolicy przybył na odpust z okazji założenia archikonfraterni literackiej. Kiedy rozniosło się, że na inauguracjej będą panowie hetmanie, siła nas wojskowych, pułkowników i rotmistrzów tam poszła. Ksiądz kanonik Żółtowski ${ }^{73}$ trzymał cudne kazanie, z któregośmy wypośrodkowali, że wszelkiemu złu winien niejaki Demokrat, któren demokracją założył i materią wymyślił... Wnet po elekcji nastała taka Szusza, że w całej Rzeczypospolitej powysychały dowcipy. Następnego zaś roku zima dość późno się rozpoczęła, że wigilię od [słowo nieczytelne - KT] Januarii obchodziliśmy.

\section{LITERATURA}

Biblioteka Polska w Paryżu, Archiwum K. Morawskiego, tymcz. 45;

Biblioteka Uniwersytecka w Toruniu, Archiwum Emigracji, Kolekcja W. Wasiutyńskiego, $\mathrm{XIV} / 4$;

„Placówka” [Paryż] 1949;

„Syrena” [Paryż] 1949.

A. Friszke, Życie polityczne emigracji, Warszawa 1999;

D. Górecki, Polskie naczelne władze państwowe na uchodźstwie w latach 1939-1990, Warszawa 2002;

R. Habielski, Kryzysy prezydenckie 1947 i 1954 roku. Ich antecedencje i nastepstwa, [w:] Warszawa nad Tamiza. Z dziejów polskiej emigracji politycznej po drugiej wojnie światowej, red. A. Friszke, Warszawa 1994;

B. Smolik, Myśl polityczna Wojciecha Wasiutyńskiego, Torun 2004;

W. Turek, Wojciech Wasiutyński 1910-1994. Biografia polityczna, Kraków 2008;

P. Ziętara, Misja ostatniej szansy. Próba zjednoczenia polskiej emigracji politycznej przez gen. Kazimierza Sosnkowskiego w latach 1952-1956, Warszawa 1995.

\footnotetext{
${ }^{69}$ (łac.) - Niech żyje Król August!

${ }^{70}$ Zygmunt Zaremba (1895-1967), polityk Polskiej Partii Socjalistycznej.

${ }^{71}$ Zygmunt Berezowski (1891-1979), polityk Stronnictwa Narodowego.

${ }_{73}^{73}$ (łac.) - lecz ojczyzna najważniejsza.

${ }^{73}$ Adam Zółtowski (1881-1958), filozof i historyk, związany z ruchem narodowym.
} 


\section{A SATIRE ON AUGUST ZALESKI, I.E. ON THE CONFLICT BETWEEN WOJCIECH WASIUTYŃŚKI AND THE PARISIAN SYRENA}

In 1949 the Parisian weekly Syrena published an anonymous satire on President August Zaleski. As it later turned out, it was written by Wojciech Wasiutyński, a well-known journalist and activist of the Stronnictwo Narodowe (National Party). Wasiutyński was not informed about the decision to publish his text and was outraged, demanding compensation. The editorial team explained that the anonymous copies of the satire had circulated among Polish immigrants. The issue echoed a far more significant debate concerning the office of the President of Poland in exile.

KEY WORDS: Wojciech Wasiutyński; August Zaleski; the Syrena weekly; the conflict concerning the office of the President of Poland in exile. 